\title{
PENGARUH PERTUMBUHAN EKONOMI DAN TINGKAT PENDIDIKAN TERHADAP DISPARITAS PENDAPATAN DI WILAYAH GERBANGKERTOSUSILA
}

\author{
Emi Nuraini, Pascasarjana Unesa \\ aini.cheeze@yahoo.com
}

\begin{abstract}
ABSTRAK
Penelitian ini bertujuan untuk menganalisis pengaruh pertumbuhan ekonomi dan tingkat pendidikan terhadap disparitas pendapatan Gerbangkertosusila baik secara parsial maupun simultan. Populasi dalam penelitian ini adalah Gerbangkertosusila tahun 2003-2012. Teknik pengambilan sampel yang digunakan adalah sampling jenuh. Adapun metode analisis menggunakan teknik analisis regresi data panel. Hasil penelitian menunjukkan (1) bahwa secara parsial pertumbuhan ekonomi tidak berpengaruh signifikan terhadap disparitas pendapatan Gerbangkertosusila. Hasil temuan menunjukkan bahwa pertumbuhan ekonomi tidak dapat terdistribusi secara merata. (2) Tingkat pendidikan berpengaruh signifikan terhadap disparitas pendapatan Gerbangkertosusila. Jumlah penduduk Kota Surabaya yang berpendidikan tinggi lebih banyak dibandingkan Keenam Kabupaten/Kota lainnya namun memiliki disparitas pendapatan yang tinggi pula. (3) Sedangkan secara simultan pertumbuhan ekonomi dan tingkat pendidikan berpengaruh signifikan terhadap disparitas pendapatan Gerbangkertosusila. Hasil temuan menunjukkan bahwa adanya perbedaan disparitas pendapatan yang lebih tinggi pada Kota Surabaya karena Kota Surabaya merupakan daerah nodal dan keenam daerah lainnya merupakan daerah pendukung sehingga kesenjangan semakin tinggi antara daerah nodal dan daerah pendukung. Diharapkan pemerintah dapat meningkatkan output sektor industri, jasa dan barang modal sehingga pertumbuhan ekonomi yang tinggi dapat tercapai dan lebih memperhatikan lagi sektor pendidikan terutama pada daerah pusat pertumbuhan.
\end{abstract}

Kata Kunci: Pertumbuhan Ekonomi, Tingkat Pendidikan, Disparitas Pendapatan Gerbangkertosusila.

\begin{abstract}
This study aims to analyze the influence of economic growth and educational level towards income disparity on Gerbangkertosusila region either partially or simultaneously. Gerbangkertosusila in 2003-2012 becomes the subject of this research. In addition, the research uses sampling saturated and regression models for panel data analysis to achieve the aims of this study.The results of this study showed that (1) partially economic growth significantly does not influence the income disparity in Gerbangkertosusila region. The invention indicates that economic growth can not be distributed evenly. (2) The level of education
\end{abstract}


have a significant effect on the income disparity of Gerbangkertosusila. The total population of high educated people in Surabaya is higher than others. So, Surabaya has higher income disparity too. (3) While simultaneously, economic growth and education level significanly influence the income disparity in Gerbangkertosusila region. The findings showed that Surabaya has different income disparity. It is because Surabaya as a capital area than other regencies as supporting area. So there is a high gap between capital and supporting area. The government is expected to be able to increase the industrial sector's output, services and capital goods so that high economic growth can be achieved and more attention to the education sector, especially in the central areas of growth. Keywords: Economic Growth, Education Level, Gerbangkertosusila Income Disparity.

\section{PENDAHULUAN}

Wujud pembangunan ekonomi terlihat dari adanya perubahan pada struktur perekonomian yang tercipta dari serangkaian usaha dalam mengembangkan perekonomian. Tujuan utama dalam pembangunan ekonomi ini diharapkan kesempatan kerja, pendapatan dan kesejahteraan masyarakat semakin meninggkat (Sukirno: 2010). Implikasi dari serangkaian usaha dalam mengembangkan perekonomian tersebut mutlak diperlukan oleh setiap negara dalam rangka menigkatkan taraf hidup dan kemakmuran masyarakat. Hal ini dapat dilakukan dengan cara mengembangkat potensi dari seluruh sektor perekonomian yang ada di negara tersebut. Keberhasilan pembangunan ekonomi suatu negara atau daerah dapat dilihat dari perubahan struktur perekonomian, pertumbuhan ekonomi dan semakin rendahnya disparitas pendapatan. Disparitas pendapatan merupakan masalah yang selalu dihadapi oleh setiap negara, terutama negara miskin dan berkembang, tidak terkecuali Gerbangkertosusila yang merupakan kawasan metropolitan. Gerbangkertosusila merupakan akronim dari Kabupaten Gresik, Kabupaten Bangkalan, Kabupaten Mojokerto, Kota Mojokerto, Kota Surabaya, Kabupaten Sidoarjo, Kabupaten Lamongan. Kawasan Gerbangkertosusila merupakan kawasan metropolitan yang berpusat di Surabaya.

Disparitas pendapatan ini muncul karena dipicu oleh beberapa faktor. Dalam beberapa penelitian disebutkan bahwa pendidikan merupakan faktor yang memegang peranan penting dalam meningkatkan atau menurunkan disparitas pendapatan. Disparitas pendidikan yang rendah cenderung menghasilakn disparitas pendapatan yang rendah begitu pula sebaliknya jika disparitas pendidikan tinggi maka disparitas pendapatan juga tinggi (Lin: 2007, Teulings \& Thijs: 2008, Abdullah: 2011, Hoi \& Lee: 2012). Di sisi lain beberapa peneliti juga mengemukakan bahwa pertumbuhan ekonomi merupakan faktor yang tidak kalah penting pengaruhnya terhadap disparitas pendapatan. Pertumbuhan ekonomi yang semakin meningkan cenderung akan menurunkan adanya disparitas pendapatan (Ibourk \& Jabrane: 2013, Szeles: 2013, Ali: 2014, Das: 2014). Sedangkan dalam penelitian lain disebutkan bahwa faktor-faktor yang mempengaruhi disparitas pendapatan adalah pertumbuhan penanaman modal asing, ekspor, dan PDRB (Sultan dan Jazani: 
2010). Namun dalam penelitian ini, peneliti akan memfokuskan pada dua faktor secara spesifik yakni pertumbuhan ekonomi dan tingkat pendidikan.

Salah satu faktor yang dapat memicu disparitas pendapatan adalah adanya perbedaan pertumbuhan ekonomi antar kabupaten/kota. Pertumbuhan ekonomi merupakan salah satu ukuran dalam keberhasilan pembangunan ekonomi di suatu daerah. Pertumbuhan ekonomi menunjukkan implikasi aktivitas perekomian terhadap bertambahnya pendapatan masyarakat pada suatu periode tertentu. Perekonomian dikatakan tumbuh ketika pendapatan riil pada tahun sebelumnya jauh lebih kecil dibandingkan balas jasa riil pada tahun tertentu. Pertumbuhan ekonomi dan disparitas pendapatan memiliki hubungan yang positif. Artinya ketika perekonomian mengalami peningkatan maka disparitas pendapatan juga akan mengikuti peningkatan perekonomian tersebut. Semakin tinggi peningkatan perekonomian semakin tinggi pula disparitas pendapatan masyarakat (Prapti: 2006). Kota Surabaya merupakan kota yang memiliki pertumbuhan ekonomi paling tinggi (6,82\%), disusul Kabupten Gresik (6,81), Kota Mojokerto (6,25\%), Kabupaten Mojokerto (6,13\%), Kabupaten Sidoarjo (6,1\%), Kabupaten Lamongan (5,95\%), dan Kabupaten Bangkalan (5,22\%) pada posisi terakhir.

Selain pertumbuhan ekonomi, ada faktor lain yang dapat mempengaruhi disparitas pendapatan antar daerah. Salah satu faktor penting lainnya selain pertumbuhan ekonomi adalah tingkat pendidikan. Pendidikan merupakan salah satu modal dasar manusia yang harus dipenuhi untuk mencapai pembangunan ekonomi yang berkelanjutan. Sektor pendidikan memainkan peran utama untuk membentuk kemampuan sebuah negara berkembang untuk menyerap teknologi modern dan mengembangkan kapasitas produksi agar tercipta pertumbuhan serta pembangunan yang berkelanjutan (Todaro, 2006). Kota Surabaya memiliki jumlah penduduk yang berpendidikan SMA paling tinggi begitu pula untuk jenjang pendidikan Perguruan Tinggi. Namun untuk jenjang pendidikan SMK, Kota mojokerto lebih dominan. Dari ketujuh Kabupaten/Kota Gerbangkertosusila dapat diketahui bahwa Kabupaten Bangkalan memiliki jumlah penduduk dengan tingkat pendidikan SMA,SMK, dan Perguruan Tinggi paling sedikit.

Secara teori Kuznets menyatakan bahwa Tingkat kemiskinan dan disparitas pendapatan akan semakin tinggi pada awal pertumbuhan ekonomi di negara-negara miskin. Namun seiring kemajuan negara tersebut maka permasalahan kemiskinan dan disparitas pendapatan akan semakin menurun (Kuncoro, 2006). Hal ini sejalan dengan hasil penelitian yang dilakukan oleh Raswita dan Made (2013) dan Ali (2014) yang menyatakan bahwa hipotesis Kuznets berlaku pada wilayah yang diteliti. Pertumbuhan ekonomi meningkatkan dampak disparitas pendapatan dan pada akhirnya semakin menurun ketika wilayah tersebut semakin maju. Dalam penelitian lain dikatakan bahwa pertumbuhan ekonomi memiliki dampak langsung maupun tidak langsung terhadap disparitas pendapatan (Ibourk, 2013 dan Szeles, 2013).

Disamping itu Kuznet menjelaskan bahwa distribusi pendapatan berhubungan dengan distribusi tingkat pendidikan. Pada masyarakat kelas bawah yang berpendapatan sangat rendah cenderung memiliki distribusi pendapatan yang merata karena faktor tingkat pendidikan yang sangat rendah pula. Distribusi pendapatan didominasi dan terkonsentrasi pada tingkat 
pendapatan yang sangat rendah. Distribusi pendidikan semakin tidak merata dengan adanya peningkatan pendapatan. Hal ini muncul akibat adanya perubahan masyarakat agraris yang berurbanisasi sehingga memicu semakin tidak merantanya distribusi pendapatan. Namun ketika distribusi pendapatan semakin merata pada tingkat pendidikan yang rata-rata tergolong tinggi, hal ini akan mengakibatkan adanya penurunan disparitas pendapatan atau distribusi pendapatan semakin merata.

Hal ini sejalan dengan teori human capital dimana ketika seseorang memiliki tingkat pendidikan yang tinggi, hal tersebut akan berdampak pada tingkat produktivitas kerjanya yang juga berdampak pada peningkatan upah ketika mereka mau berinvestasi pada pendidikan. Dalam penelitian Teulings (2008) juga disebutkan bahwa setiap kenaikan satu tahun di tingkat pendidikan dapat mengurangi disparitas pendapatan sebesar 2\%. Semakin tinggi tingkat disparitas pendidikan maka semakin tinggi pula disparitas pendapatan begitu pula sebaliknya (Lin, 2007 dan Abdullah, 2011).

Orang yang berpendidikan tinggi memulai kerja purnawaktunya pada usia yang lebih tua, namun pendapatan mereka dengan cepat melampau orangorang yang bekerja lebih awal (Todaro \& Stephen, 2006). Hal ini menggambarkan bahwa mereka yang telah memasuki usia kerja dan lebih memilih untuk berinvestasi dalam pendidikan akan berdampak pada pendapatannya kelak. Semakin tinggi tingkat pendidikan maka semakin tinggi pula pendapatan yang diterima.

\section{METODE PENELITIAN}

Jenis penelitian ini adalah penelitian asosiatif kausal. Penelitian asosiatif kausal merupakan jenis penelitian yang bertujuan untuk menganalisis hubungan antar variabel yang saling terkait satu sama lainnya yang menjelaskan bagaimana suatu varibel dapat mempengaruhi variabel lainnya (Sugiyono, 2011). Dengan kata lain desain kausal dapat menjelaskan hubungan antara satu variabel dengan variabel lainnya yang saling mempengaruhi. Dalam penelitian ini bertujuan untuk menjelaskan pengaruh pertumbuhan ekonomi dan tingkat pendidikan terhadap disparitas pendapatan Gerbangkertosusila. Dalam penelitian ini terdiri dari dua variabel bebas yaitu pertumbuhan ekonomi $\left(\mathrm{X}_{1}\right)$ dan tingkat pendidikan $\left(\mathrm{X}_{2}\right)$, dan satu variabel terikatnya yakni disparitas pendapatan (Y). Jenis pengambilan sampel yang digunakan adalah sampling jenuh yaitu teknik penentuan sampel dengan mengambil populasi sebagai sampel (Sugiyono, 2011). Sampel dalam penelitian ini adalah Gerbangkertosusila periode tahun 2003-2012. Data dalam penelitian ini adalah data sekunder dimana data tersebut sudah tersedia sehingga data tersebut diperoleh peneliti dengan metode dokumentasi, yaitu suatu cara memperoleh data atau informasi tentang hal-hal yang ada kaitannya dengan penelitian dengan jalan melihat kembali laporan tertulis yang lalu baik berupa angka maupun keterangan (Arikunto, 2006). Data dalam penelitian ini diperoleh dari Badan Pusat Statistik (BPS). Teknik analisis data yang digunakan dalam penelitian ini adalah teknik analisis regresi data panel. 


\section{HASIL PENELITIAN DAN PEMBAHASAN}

Struktur ekonomi suatu wilayah dapat dilihat dari kontribusi masingmasing Sektor ekonomi terhadap pembentukan angka PDRB. Oleh karena itu struktur ekonomi dapat menggambarkan tipe/karakteristik suatu wilayah. Jika dalam suatu daerah lebih terdominasi oleh Sektor primer maka daerah tersebut tergolong tipe agraris (agriculture). Apabila Sektor sekunder yang lebih mendominasi maka daerah tersebut tergolong tipe industri (manufacture). Secara umum diketahui sektor yang mendominasi di Gerbangkertosusila (Kabupaten Gresik, Kabupaten Bangkalan, Kabupaten Mojokerto, Kota Mojokerto, Kota Surabaya, Kabupaten Sidoarjo,Kabupaten Lamongan) adalah Sektor primer, sekunder atau tersier namun kontribusi terbesar terhadap PDRB jika dilihat per Sektornya justru berbeda. Hal ini menggambarkan Sektor yang paling berkembang dan berpotensi besar di daerah tersebut. Seperti Kabupaten Gresik yang didominasi Sektor tersier karena Sektor tersier adalah akumulasi dari empat Sektor yakni sektor perdagangan, hotel dan restoran, sektor pengangkutan dan komunikasi, sektor keuangan, persewaan, dan jasa perusahaan, serta sektor jasa-jasa. Namun jika dilihat per Sektor maka Sektor industri pengolahan yang tergolong dalam Sektor sekunder yang memiliki kontribusi terbesar dalam PDRB Kabupaten Gresik. Begitupun yang terjadi pada Kabupaten Bangkalan dan Sidoarjo.

Indikator yang sering digunakan sebagai dasar analisis untuk mengukur kinerja ekonomi suatu daerah pada suatu periode tertentu (kenaikan produksi barang dan jasa) ialah pertumbuhan ekonomi. Semakin tinggi angka pertumbuhan ekonomi suatu daerah maka mengindikasikan bahwa output dari kegiatan ekonomi daerah tersebut juga mengalami peningkatan. Berikut gambaran pertumbuhan ekonomi Gerbangkertosusila sepanjang tahun 20032012:

Tabel 1. Pertumbuhan Ekonomi Gerbangkertosusila

\begin{tabular}{|c|c|c|c|c|c|c|c|}
\hline Tahun & $\begin{array}{c}\text { Kab. } \\
\text { Gresik }\end{array}$ & $\begin{array}{c}\text { Kab } \\
\text { Bangkalan }\end{array}$ & $\begin{array}{c}\text { Kab. } \\
\text { Mojokerto }\end{array}$ & $\begin{array}{c}\text { Kota } \\
\text { Mojokerto }\end{array}$ & $\begin{array}{c}\text { Kota } \\
\text { Surabaya }\end{array}$ & $\begin{array}{c}\text { Kab. } \\
\text { Sidoarjo }\end{array}$ & $\begin{array}{c}\text { Kab. } \\
\text { Lamongan }\end{array}$ \\
\hline 2003 & 5.07 & 4.41 & 4.8 & 6.08 & 5.29 & 5.13 & 4.06 \\
\hline 2004 & 6.61 & 4.73 & 5.68 & 6.18 & 6.8 & 6.15 & 4.84 \\
\hline 2005 & 7.78 & 4.67 & 6.93 & 6.08 & 7.35 & 6.59 & 5.81 \\
\hline 2006 & 6.94 & 4.57 & 5.13 & 5.26 & 6.64 & 5.81 & 5.48 \\
\hline 2007 & 6.88 & 5 & 5.44 & 6.39 & 6.74 & 5.73 & 5.94 \\
\hline 2008 & 6.17 & 4.71 & 5.87 & 5.71 & 6.84 & 4.95 & 6.22 \\
\hline 2009 & 5.96 & 4.37 & 5.03 & 5.03 & 5.17 & 4.41 & 5.31 \\
\hline 2010 & 6.89 & 5.47 & 6.87 & 6.66 & 7.47 & 5.92 & 6.85 \\
\hline 2011 & 7.39 & 6.27 & 7.23 & 6.77 & 7.65 & 6.96 & 7.07 \\
\hline 2012 & 7.43 & 6.45 & 7.29 & 7.19 & 7.76 & 7.23 & 7.22 \\
\hline
\end{tabular}

Sumber: Data Badan Pusat Statistik Jawa Timur (2013)

Dari tabel 1 dapat diketahui bahwa pertumbuhahn ekonomi Gerbangkertosusila cukup fluktuatif setiap tahunnya. Hal ini terjadi karena beberapa indicator pertumbuhan ekonomi mengalami naik turun pada jumlah output tiap tahunnya. Dari ketujuh Kabupaten/Kota rata-rata mengalami penurunan pertumbuhan ekonomi pada tahun 2006 dan 2009. Namun pada tahun 2008 Kabupaten Gresik, Kabupaten Bangkalan, Kota Mojokerto dan 
Kabupaten Sidoarjo juga mengalami penurunan. Sedangkan data pendidikan yang dipakai dalam penelitian ini adalah data penduduk Gerbangkertosusila yang berusia 15 tahun ke atas yang minimal pendidikan terakhirnya SMA dimana pada usia tersebut merupakan usia kerja produktif. Berikut merupakan data tingkat pendidikan penduduk Gerbangkertosusila:

Tabel 2. Tingkat Pendidikan Minimal SMA Penduduk Gerbangkertosusila

\begin{tabular}{|c|c|c|c|c|c|c|c|}
\hline Tahun & $\begin{array}{c}\text { Kab. } \\
\text { Gresik }\end{array}$ & $\begin{array}{c}\text { Kab } \\
\text { Bangkalan }\end{array}$ & $\begin{array}{c}\text { Kab. } \\
\text { Mojokerto }\end{array}$ & $\begin{array}{c}\text { Kota } \\
\text { Mojokerto }\end{array}$ & $\begin{array}{c}\text { Kota } \\
\text { Surabaya }\end{array}$ & $\begin{array}{c}\text { Kab. } \\
\text { Sidoarjo }\end{array}$ & $\begin{array}{c}\text { Kab. } \\
\text { Lamongan }\end{array}$ \\
\hline 2003 & 767069 & 611499 & 717897 & 84247 & 2061278 & 1271159 & 927050 \\
\hline 2004 & 809793 & 621039 & 717476 & 87796 & 2037672 & 1274594 & 935041 \\
\hline 2005 & 805803 & 645064 & 744540 & 89058 & 2124436 & 1363178 & 940288 \\
\hline 2006 & 843342 & 686998 & 784047 & 91115 & 2097766 & 1354942 & 974160 \\
\hline 2007 & 833526 & 665533 & 774520 & 90098 & 2055628 & 1396347 & 972895 \\
\hline 2008 & 838542 & 684724 & 751874 & 88281 & 1999554 & 1270286 & 931776 \\
\hline 2009 & 965842 & 696861 & 738685 & 86768 & 2090541 & 1451610 & 924582 \\
\hline 2010 & 827336 & 566567 & 752836 & 88880 & 2002929 & 1356826 & 865674 \\
\hline 2011 & 910630 & 653036 & 785409 & 94341 & 2153957 & 1460958 & 899322 \\
\hline 2012 & 557623 & 455143 & 546155 & 64894 & 1419677 & 984910 & 618831 \\
\hline
\end{tabular}

Sumber: Data Badan Pusat Statistik Jawa Timur (2013)

Dari tabel 2 diketahui bahwa Kota Surabaya memiliki jumlah penduduk dengan pendidikan minimal SMA terbanyak jika dibandingkan dengan keenam Kabupaten/Kota lainnya. Sedangkan Kota Mojokerto memiliki jumlah penduduk berpendidikan minimal SMA paling sedikit. Namun jika dibandingkan tidaklah sebanding karena jumlah penduduk Kota Surabaya jauh lebih banyak dibandingakan jumlah penduduk Kota Mojokerto. Jika diubah dalam bentuk persentase maka akan terlihat perbedaannya antara jumlah pendudukan yang berpendidikan tinggi dibanding jumlah penduduk masingmasing daerah. Disamping tingkat pertumbuhan ekonomi dan tingkat pendidikan, berikut juga disajikan data disparitas pendapatan Gerbangkertosusila. Disparitas pendapatan menggambarkan ketidakmerataan pendapatan di Gerbangkertosusila. Adapun tinggi rendahnya disparitas pendapatan di Gerbangkertosusila dapat dilihat pada tabel berikut:

Tabel 3. Disparitas Pendapatan Gerbangkertosusila

\begin{tabular}{|c|l|c|c|c|c|c|c|c|c|c|c|}
\hline No & KAB/KOTA & $\mathbf{2 0 0 3}$ & $\mathbf{2 0 0 4}$ & $\mathbf{2 0 0 5}$ & $\mathbf{2 0 0 6}$ & $\mathbf{2 0 0 7}$ & $\mathbf{2 0 0 8}$ & $\mathbf{2 0 0 9}$ & $\mathbf{2 0 1 0}$ & $\mathbf{2 0 1 1}$ & $\mathbf{2 0 1 2}$ \\
\hline 1 & Kab. Gresik & 0.07 & 0.06 & 0.06 & 0.02 & 0.04 & 0.03 & 0.06 & 0.05 & 0.05 & 0.19 \\
\hline 2 & Kab. Bangkalan & 0.25 & 0.22 & 0.21 & 0.07 & 0.23 & 0.24 & 0.23 & 0.23 & 0.22 & 0.22 \\
\hline 3 & Kab. Mojokerto & 0.16 & 0.16 & 0.16 & 0.05 & 0.16 & 0.17 & 0.12 & 0.12 & 0.12 & 0.12 \\
\hline 4 & Kota Mojokerto & 0.03 & 0.01 & 0.01 & 0 & 0.01 & 0.01 & 0.02 & 0.02 & 0.02 & 0.03 \\
\hline 5 & Kota Surabaya & 0.17 & 0.8 & 0.8 & 0.26 & 0.87 & 0.91 & 0.88 & 0.89 & 0.92 & 0.93 \\
\hline 6 & Kab. Sidoarjo & 0.19 & 0.15 & 0.14 & 0.04 & 0.11 & 0.11 & 0.04 & 0.03 & 0.03 & 0.02 \\
\hline 7 & Kab. Lamongan & 0.32 & 0.26 & 0.26 & 0.08 & 0.26 & 0.26 & 0.24 & 0.23 & 0.23 & 0.23 \\
\hline
\end{tabular}


Pada tabel 3 jelas terlihat bahwa disparitas pendapatan dari tujuh kabupaten/kota Gerbangkertosusila tergolong rendah kecuali Kota Surabaya. Disparitas pendapatan di Surabaya pada tahun 2003 tergolong rendah yakni 0,17 namun pada tahun 2004 -2005 disparitas pendapatan meningkat tergolong dalam kategori tinggi. Pada tahun 2007 turun kembali dan meningkat kembali pada tahun 2007-2012 dalam kategori tinggi. Hal ini menggambarkan bahwa dari ketujuh kabupaten/kota Gerbangkertosusila, hanya di Kota Surabaya yang mengalami ketidak merataan pendapatan yang tinggi.

Dalam penelitian ini tidak perlu dilakukan uji asumsi klasik karena beberapa keunggulan yang dimiliki analisis regresi data panel (Gujarati dalam Shochrul dkk: 2011). Adapun uji yang harus dilewati untuk menentukan model regresi yang digunakan adalah uji F-stat atau Uji Chow. Uji chow ini dilakukan untuk memilih model data panel yang paling baik atau sesuai antara model common effect/OLS atau fixed effect. Dari hasil uji Chow dapat diketahui bahwa $\mathrm{P}$ value cross section $\mathrm{F}<\alpha$ yakni $0,0000<0,05$ maka $\mathrm{H} 0$ ditolak. Artinya model yang lebih baik untuk digunakan adalah model fixed effect. Oleh karena itu perlu dilakukan uji hausman. Uji Hausman dilakukan untuk mengetahui model yang lebih baik antara fixed effect dan random effect. Hasil Uji Hausman sejalan dengan hasil Uji Chow dimana model regresi yang paling baik adalah model regresi fixed effect.

Setelah ditentukan model regresi yang paling baik kemudian dilakukan uji t. Jika t-hitung $>$ t-tabel atau $\mathrm{p}$ value $<0,05$, maka $\mathrm{H} 0$ ditolak, artinya salah satu variabel independen mempengaruhi variabel dependen secara signifikan. Jika t-hitung $<\mathrm{t}$-tabel atau $\mathrm{p}$ value $>0,05$, maka $\mathrm{H} 0$ diteriman, artinya salah satu variabel independen tidak mempengaruhi variabel dependen secara signifikan (Gujarati: 2006). Dari hasil uji t diketahui bahwa variabel pertumbuhan ekonomi (PE) terhadap disparitas pendapatan $(\mathrm{Vw})$ dengan nilai signifikansi 0,2891 >0,05. Dengan demikian hipotesis nol diterima, artinya variabel pertumbuhan ekonomi tidak berpengaruh signifikan terhadap disparitas pendapatan Gerbangkertosusila. Variabel tingkat pendidikan (TP) terhadap disparitas pendapatan ( $\mathrm{Vw}$ ) dengan nilai signifikansi sebesar $0,0033<$ 0,05. Dengan demikian hipotesis nol ditolak, artinya variabel tingkat pendidikan mempunyai pengaruh yang signifikan terhadap disparitas pendapatan Gerbangkertosusila. Uji yang selanjutnya adalah uji $\mathrm{F}$, uji $\mathrm{F}$ digunakan untuk menguji hipotesis yang melibatkan lebih dari satu koefisien (Sarwoko: 2005). Uji F ini bertujuan untuk menunjukkan apakah semua variabel independen yaitu pertumbuhan ekonomi dan tingkat pendidikan yang dimasukkan ke dalam model mempunyai pengaruh secara bersama-sama terhadap variabel dependen yaitu disparitas pendapatan. Berdasarkan hasil Uji $\mathrm{F}$ untuk kedua variabel yaitu pertumbuhan ekonomi (PE) dan tingkat pendidikan (TP) terhadap disparitas pendapatan Gerbangkertosusila diketahui bahwa nilai signifikansi sebesar $0,000000<0,05$. Dengan demikian $\mathrm{H}_{0}$ ditolak, yang artinya variabel pertumbuhan ekonomi (PE) dan tingkat pendidikan (TP) berpengaruh signifikan terhadap variabel disparitas pendapatan $(\mathrm{Vw})$.

Seberapa besar pengaruh variabel independen yaitu pertumbuhan ekonomi terhadap variabel dependen yaitu disparitas pendapatan dapat dilihat melalui R-square. Jika $\mathrm{R}^{2}$ semakin mendekati satu, berarti kemampuan variabel-variabel bebas dapat menjelaskan hampir semua informasi yang 
digunakan untuk memprediksi variasi variabel terikat. Diketahui bahwa nilai $\mathrm{R}$ square sebesar 0,872673 . Hal ini berarti bahwa $87,27 \%$ disparitas pendapatan Gerbangkertosusila dapat dijelaskan oleh kedua variabel pertumbuhan ekonomi dan tingkat pendidikan, sedangkan sisanya sebesar 12,73\% dipengaruhi oleh faktor-faktor lain di luar variabel yang diteliti.

Hasil estimasi model regresi panel Gerbangkertosusila dengan Eviews 6 menunjukkan bahwa $\mathrm{Vw}=0,339+0,005 \mathrm{PE}-4,69 \mathrm{TP}+$ e. Artinya nilai konstanta (a) sebesar 0,339 artinya jika terjadi perubahan nilai variabel pertumbuhan ekonomi $\left(\mathrm{X}_{1}\right)$ dan tingkat pendidikan $\left(\mathrm{X}_{2}\right)$ maka disparitas pendapatan (Y) yang akan terjadi sebesar 0,339\%. Koefisien regresi pertumbuhan ekonomi $\left(\mathrm{X}_{1}\right)$ sebesar 0,005 , artinya setiap perubahan variabel pertumbuhan ekonomi $\left(\mathrm{X}_{1}\right)$ akan berpengaruh positif terhadap disparitas pendapatan (Y) sebesar 0,005 dengan asumsi variabel tingkat pendidikan tetap $\left(\mathrm{X}_{2}\right)$. Nilai koefisien regresi positif menunjukkan pengaruh yang ditimbulkan searah. Jika variabel pertumbuhan ekonomi $\left(\mathrm{X}_{1}\right)$ naik $1 \%$ maka akan berpengaruh pada kenaikan disparitas pendapatan (Y) sebesar $0,005 \%$, begitu pula sebaliknya jika variabel pertumbuhan ekonomi $\left(\mathrm{X}_{1}\right)$ turun $1 \%$ makan akan berdampak pada penurunan disparitas pendapatan sebesar (Y) 0,005\%. Koefisien regresi tingkat pendidikan $\left(\mathrm{X}_{2}\right)$ sebesar - 4,69, artinya setiap perubahan variabel tingkat pendidikan $\left(\mathrm{X}_{2}\right)$ akan berpengaruh negatif terhadap disparitas pendapatan (Y) sebesar -4,69 dengan asumsi variabel pertumbuhan ekonomi $\left(\mathrm{X}_{1}\right)$ tetap. Nilai koefisien regresi negatif menunjukkan pengaruh yang ditimbulkan tidak searah. Jika variabel tingkat pendidikan $\left(\mathrm{X}_{2}\right)$ naik $1 \%$ maka akan berpengaruh pada penurunan disparitas pendapatan (Y) sebesar $4,69 \%$, begitu pula sebaliknya jika variabel tingkat pendidikan $\left(\mathrm{X}_{2}\right)$ turun $1 \%$ makan akan berdampak pada kenaikan disparitas pendapatan sebesar (Y) $4,69 \%$.

Koefisien dari variabel pertumbuhan ekonomi adalah 0,005 artinya jika variabel pertumbuhan ekonomi bertambah 1\% sedangkan variabel tingkat pendidikan tetap, maka ketimpangan pendidikan akan mengalami kenaikan sebesar $0,005 \%$. Tanda $(+)$ positif menunjukkan adanya hubungan searah antara pertumbuhan ekonomi dan disparitas pendapatan Gerbangkertosusilo. Jika pertumbuhan ekonomi tinggi maka disparitas pendapatan juga akan tinggi pula. Koefisien dari variabel tingkat pendidikan ekonomi adalah -4,688 artinya jika variabel tingkat pendidikan bertambah $1 \%$ sedangkan variabel pertumbuhan ekonomi tetap, maka ketimpangan pendidikan akan mengalami kenaikan sebesar 4,688\%. Tanda (-) negatif menunjukkan adanya hubungan berbanding terbalik antara tingkat pendidikan dan disparitas pendapatan Gerbangkertosusilo. Jika tingkat pendidikan tinggi maka disparitas pendapatan menurun.

Penelitian ini telah menguji tiga hipotesis sebagaimana yang telah diuraikan sebelumnya. Berdasarkan hasil uji hipotesis disimpulkan bahwa tidak semua hipotesis terbukti atau diterima. Secara parsial variabel pertumbuhan ekonomi terbukti tidak berpengaruh signifikan terhadap disparitas pendapatan Gerbangkertosusila (Kabupaten Gresik, Kabupaten Bangkalan, Kabupaten Mojokerto, Kota Mojokerto, Kota Surabaya, Kabupaten Sidoarjo,Kabupaten Lamongan). Sedangkan variabel tingkat pendidikan secara parsial berpengaruh terhadap disparitas pendapatan Gerbangkertosusila (Kabupaten Gresik, 
Kabupaten Bangkalan, Kabupaten Mojokerto, Kota Mojokerto, Kota Surabaya, Kabupaten Sidoarjo,Kabupaten Lamongan). Hasil pengujian secara simultan terbukti bahwa kedua variabel independen yakni pertumbuhan ekonomi dan tingkat pendidikan berpengatuh signifikan terhadap disparitas pendapatan Gerbangkertosusila (Kabupaten Gresik, Kabupaten Bangkalan, Kabupaten Mojokerto, Kota Mojokerto, Kota Surabaya, Kabupaten Sidoarjo,Kabupaten Lamongan). Untuk lebih memperjelas hasil analisis pengujian hipotesis berikut akan dijelaskan diskusi hasil penelitian:

Berdasarkan hasil analisis pengujian dengan menggunakan Eviews 6 menunjukkan bahwa tidak terdapat pengaruh dan terdapat hubungan yang positif antara pertumbuhan ekonomi dengan disparitas pendapatan Gerbangkertosusila (Kabupaten Gresik, Kabupaten Bangkalan, Kabupaten Mojokerto, Kota Mojokerto, Kota Surabaya, Kabupaten Sidoarjo,Kabupaten Lamongan) berdasarkan model regresi yang terbentuk. Hal ini memberikan pengertian bahwa tinggi rendahnya pertumbuhan ekonomi tidak berpengaruh terhadap tinggi rendahnya disparitas pendapatan Gerbangkertosusila (Kabupaten Gresik, Kabupaten Bangkalan, Kabupaten Mojokerto, Kota Mojokerto, Kota Surabaya, Kabupaten Sidoarjo,Kabupaten Lamongan).

Hasil penelitian ini menolak teori yang dikemukakan oleh Marx dimana pertumbuhan ekonomi akan cenderung mengurangi dampak kemiskinan dan disparitas pendapatan, artinya semakin tinggi pertumbuhan ekonomi akan mengurangi kondisi disparitas pendapatan, begitu pula sebaliknya (Deliarnov: 2009). Hasil penelitian ini juga tidak sesuai dengan teori yang disampaikan oleh Kuznet yang menyatakan bahwa pertumbuhan ekonomi memiliki hubungan yang positif dengan disparitas pendapatan. Artinya semakin tinggi tingkat pertumbuhan ekonomi maka semakin tinggi dampak disparitas pendapatan suatu daerah (Kuncoro: 2006).

Hasil penelitian ini tidak sesuai dengan penelitian sebelumnya yang dilakukan oleh Riandoko (2013), Raswita dan Made (2013), Ibourk (2013), Szeles (2013), Ali (2014), dan Das (2014) yang menyimpulkan bahwa pertumbuhan ekonomi berpengaruh terhadap disparitas pendapatan secara parsial. Namun hasil penelitian ini sesuai dengan penelitian sebelumnya yang dilakukan oleh Lee (2013) dimana pertumbuhan ekonomi tidak berpengaruh terhadap disparitas pendapatan. Dari beberapa pendapat para pakar dan hasil penelitian terdahulu di atas maka dapat dikatakan bahwa pertumbuhan ekonomi yang tinggi tidak bisa menjamin adanya pemerataan distribusi pendapatan.

Rata-rata pertumbuhan ekonomi dari ketujuh Kabupaten/Kota menunjukkan bahwa Kota Surabaya dan Kabupaten Gresik memiliki rata-rata pertumbuhan ekonomi tertinggi yakni 6,82 dan 6,81 dengan selisih 0,01. Namun jika melihat disparitas pendapatan Kota Surabaya dan Kabupaten Gresik jauh berbeda. Kota Surabaya tergolong Kota yang memiliki disparitas pendapatan tinggi, sedangkan Kabupaten Gresik tergolong dalam kategori rendah. Pada tahun 2005 terjadi peningkatan pertumbuhan ekonomi dari 6,80 menjadi 7,35 namum disparitas pendapatan tetap sebesar 0,8 . Begitu juga yang terjadi pada tahun 2007 terjadi peningkatan pertumbuhan ekonomi dari 6,64 menjadi 6,74 dengan selisih pertumbuhan sebesar 0,10 namun disparitas pendapatan mengalami peningkatan yang tinggi dari 0,26 menjadi 0,80 . 
Awalnya tergolong dalam disparitas yang rendah kemudian meningkat menjadi disparitas yang tergolong tinggi. Hal ini membuktikan bahwa tinggi atau rendahnya pertumbuhan ekonomi tidak berpengaruh pada tinggi rendahnya disparitas pendapatan.

Tidak berpengaruhnya pertumbuhan ekonomi terhadap disparitas pendapatan dilatar belakangi oleh beberapa hal termasuk kondisi perekonomian masing-masing daerah yang dijadikan sebagai objek penelitian. Kondisi perekonomian Gerbangkertosusila (Kabupaten Gresik, Kabupaten Bangkalan, Kabupaten Mojokerto, Kota Mojokerto, Kota Surabaya, Kabupaten Sidoarjo,Kabupaten Lamongan) dapat dilihat melalui pertumbuhan ekonomi masing-masing daerah, dimana pertumbuhan ekonomi merupakan peningkatan produksi barang dan jasa secara fisik dalam kurun waktu tertentu. Peningkatan produksi barang dan jasa tersebut dapat dilihat dari bertambahnya produksi barang industri, bertambahnya produksi barang modal dan bertambahnya produksi sektor jasa.

Jika melihat pada masing-masing indikator pertumbuhan ekonomi maka dapat diketahui bahwa pada indikator pertambahan produksi barang industri dari beberapa Kabupaten/Kota Gerbangkertosusila (Kabupaten Gresik, Kabupaten Bangkalan, Kabupaten Mojokerto, Kota Mojokerto, Kota Surabaya, Kabupaten Sidoarjo,Kabupaten Lamongan) mengalami penurunan. Produksi barang industri di Kabupaten Gresik pada tahun 2009-2012 terus mengalami penurunan dari 51,35\%, 50,73\%, 50,06\%, dan 49,39\%. Kabupaten Bangkalan juga mengalami penurunan kapasitas produksi barang industri pada tahun 2009 dari $4,06 \%$ menjadi $4,03 \%$ dan pada 2011 dari $4,11 \%$ menjadi $4,08 \%$.

Sedangkan pada indikator pertambahan produksi sektor jasa diketahui bahwa Kabupaten Gresik dan Kota Mojokerto mengalami penurunan produksi pada tahun 2011 dan 2012. Sedangkan produksi sektor jasa di Kabupaten Bangkalan turun pada tahun 2009. Disamping itu, indikator pertambahan produksi barang modal mengalami hal yang sama, yakni pada tahun 2009-2012 mengalami penurunan, terutama di Kabupaten Gresik. Dan Kabupaten bangkalan pada tahun 2009 dan 2011. Besar kecilnya penurunan akan berdampak pada pertumbuhan ekonomi daerah tersebut.

Dari beberapa Kabupaten/Kota Gerbangkertosusila (Kabupaten Gresik, Kabupaten Bangkalan, Kabupaten Mojokerto, Kota Mojokerto, Kota Surabaya, Kabupaten Sidoarjo,Kabupaten Lamongan) mengalami penurunan produksi baik sektor industri maupun jasa. Tidak dapat dipungkiri bahwa hal inilah merupakan bagian yang menentukan tinggi rendahnya pertumbuhan ekonomi suatu daerah. Disamping itu jika terjadi peningkatan output dari beberapa indikator pertumbuhan ekonomi, peningkatan tersebut tidak dapat terdistribusi secara merata pada tiap lapisan masyarakat dan hanya terkonsentrasi pada golongan masyarakat kelas atas atau para pemilik modal. Sehingga tingginya pertumbuhan ekonomi tidak dapat menurunkan disparitas pendapatan. Hal inilah yang melatar belakangi tidak berpengaruhnya pertumbuhan ekonomi terhadap disparitas pendapatan Gerbangkertosusila (Kabupaten Gresik, Kabupaten Bangkalan, Kabupaten Mojokerto, Kota Mojokerto, Kota Surabaya, Kabupaten Sidoarjo,Kabupaten Lamongan).

Dari pembahasan di atas dapat disimpulkan bahwa hipotesis yang menyatakan bahwa diduga ada pengaruh pertumbuhan ekonomi terhadap 
disparitas pendapatan Gerbangkertosusila (Kabupaten Gresik, Kabupaten Bangkalan, Kabupaten Mojokerto, Kota Mojokerto, Kota Surabaya, Kabupaten Sidoarjo,Kabupaten Lamongan) tidak dapat diterima atau tidak terbukti kebenarannya.

Sedangkan hipotesis kedua, Berdasarkan hasil analisis dengan pengujian menggunakan Eviews 6 menunjukkan bahwa secara parsial tingkat pendidikan memiliki pengaruh signifikan terhadap disparitas pendapatan Gerbangkertosusila (Kabupaten Gresik, Kabupaten Bangkalan, Kabupaten Mojokerto, Kota Mojokerto, Kota Surabaya, Kabupaten Sidoarjo,Kabupaten Lamongan) dan terdapat hubungan yang negatif. Hal ini menunjukkan bahwa tingkat pendidikan dan disparitas pendapatan memiliki hubungan yang negatif, artinya semakin rendah tingkat pendidikan penduduk Gerbangkertosusila (Kabupaten Gresik, Kabupaten Bangkalan, Kabupaten Mojokerto, Kota Mojokerto, Kota Surabaya, Kabupaten Sidoarjo,Kabupaten Lamongan) maka maka akan berimplikasi pada peningkatan disparitas pendapatan Gerbangkertosusila (Kabupaten Gresik, Kabupaten Bangkalan, Kabupaten Mojokerto, Kota Mojokerto, Kota Surabaya, Kabupaten Sidoarjo,Kabupaten Lamongan). Begitupun sebaliknya, semakin tinggi tingkat pendidikan penduduk maka akan diiringi dengan penurunan disparitas pendapatan Gerbangkertosusila (Kabupaten Gresik, Kabupaten Bangkalan, Kabupaten Mojokerto, Kota Mojokerto, Kota Surabaya, Kabupaten Sidoarjo,Kabupaten Lamongan).

Keadaan tersebut sesuai dengan teori yang diungkapkan oleh Spence (dalam Juwita dan Retno: 2013) yang menyatakan bahwa tingkat pendidikan dapat mempengaruhi tingkat pendapatan. Tingkat pendidikan berimplikasi pada tingkat produktivitas kerja yang mampu meningkatkan output dan pendapatan daerah secara komulatif. Pendapat tersebut juga didukung oleh Todaro dan Stephen (2006) yang mengemukakan bahwa mereka yang telah memasuki usia kerja yakni 15 tahun ke atas dan lebih memilih untuk berinvestasi dalam pendidikan maka akan berdampak pada pendapatannya kelak. Semakin tinggi tingkat pendidikan maka semakin tinggi pula pendapatan yang diterima. Meskipun orang-orang yang berpendidikan tinggi memulai kerja purnawaktunya pada usia yang lebih tua, namun pendapatan mereka dengan cepat melampau orang-orang yang bekerja lebih awal. Begitu juga menurut Kuznet dkk (dalam Carnoy et al: 2012) yang menyatakan bahwa semakin tinggi tingkat pendidikan masyarakat maka akan diikuti dengan pemerataan pendapatan. Dengan kata lain tingkat pendidikan memiliki pengaruh negatif terhadap disparitas pendapatan. Semakin tinggi tingkat pendidikan maka semakin rendah disparitas pendapatan yang tercipta. Hasil penelitian ini juga sejalan dengan penelitian terdahulu yang dilakukan oleh Lin (2007), Teulings dan Thijs (2008) dan Abdullah (2011) yang menjelaskan bahwa setiap kenaikan pada tingkat pendidikan dapat menurunkan disparitas pendapatan.

Sehingga dapat dikatakan bahwa adanya peningkatan tingkat pendidikan dapat menjamin adanya penurunan disparitas pendapatan Gerbangkertosusila (Kabupaten Gresik, Kabupaten Bangkalan, Kabupaten Mojokerto, Kota Mojokerto, Kota Surabaya, Kabupaten Sidoarjo,Kabupaten Lamongan) karena sesuai atau sejalan dengan teori dan penelitian terdahulu yang menyebutkan 
semakin tinggi tingkat pendidikan maka semakin rendah disparitas pendapatan. Dalam penelitian lain juga disebutkan bahwa tingkat pendidikan minimal SMA berpengaruh terhadap disparitas PDRB per kapita yang tidak lain merupakan indikator disparitas pendapatan (Gama: 2007).

Jika dilihat dari ketujuh Kabupaten/Kota Gerbangkertosusila (Kabupaten Gresik, Kabupaten Bangkalan, Kabupaten Mojokerto, Kota Mojokerto, Kota Surabaya, Kabupaten Sidoarjo,Kabupaten Lamongan) yang memiliki jumlah penduduk dengan tingkat pendidikan tertingi terbanyak adalah Kota Surabaya. Namun disparitas pendapatan tertinggi juga terjadi di Kota Surabaya. Memang jika dibandingkan dengan keenam Kabupaten/Kota lainnya, Kota Surabaya memiliki jumlah penduduk dengan pendidikan tertinggi terbanyak, namun jika dilihat lebih jauh proporsi tersebut hanya jumlah yang sangat kecil jika dibandingkan dengan jumlah penduduk Kota Surabaya. Pada tahun 2003-2012 penduduk Kota Surabaya yang memiliki pendidikan minimal SMA hanya berkisar rata-rata $0,37 \%$ dari jumlah keseluruhan penduduk Kota Surabaya dengan proporsi berturut-turut $0,36 \%, 0,35 \%, 0,40 \%, 0,39 \%, 0,37 \%, 0,36 \%$, $0,39 \%, 0,38 \%, 0,39 \%$, dan $0,29 \%$. Hal ini menggambarkan bahwa jumlah penduduk Kota Surabaya yang berpendidikan tinggi tergolong sangat sedikit.

Oleh karena itu hipotesis yang menyatakan diduga ada pengaruh tingkat pendidikan terhadap disparitas pendapatan Gerbangkertosusila (Kabupaten Gresik, Kabupaten Bangkalan, Kabupaten Mojokerto, Kota Mojokerto, Kota Surabaya, Kabupaten Sidoarjo,Kabupaten Lamongan) diterima.

Berdasarkan hasil analisis pengujian untuk hipotesis ketiga menunjukkan bahwa pertumbuhan ekonomi dan tingkat pendidikan berpengaruh signifikan terhadap disparitas pendapatan. Hal ini menunjukkan bahwa variabel independen yaitu pertumbuhan ekonomi dan tingkat pendidikan berpengaruh signifikan terhadap variabel disparitas pendapatan. Hasil penelitian ini mendukung hasil penelitian yang dilakukan oleh Teuling dan Thijs (2008) yang mendapati hasil bahwa pertumbuhan ekonomi dan tingkat pendidikan berpengaruh terhadap disparitas pendapatan.

Berdasarkan kenyataan di lapangan seperti halnya kawasan Jabodetabek yang menjadikan Jakarta sebagai pusat kegiatan ekonominya, Gerbangkertosusila (Kabupaten Gresik, Kabupaten Bangkalan, Kabupaten Mojokerto, Kota Mojokerto, Kota Surabaya, Kabupaten Sidoarjo,Kabupaten Lamongan) dengan Kota Surabaya sebagai pusat kegiatan ekonomi merupakan bentuk dari daerah nodal. Daerah nodal merupakan areal-areal yang strukturnya terdiri atas areal inti dengan areal-areal sekitarnya yang melengkapi sebagai suatu ekonomi ruang yang dikuasai oleh satu atau beberapa pusat kegiatan ekonominya (Arsyad: 2010). Dengan kata lain Gerbangkertosusila (Kabupaten Gresik, Kabupaten Bangkalan, Kabupaten Mojokerto, Kota Mojokerto, Kota Surabaya, Kabupaten Sidoarjo,Kabupaten Lamongan) memiliki Kota Surabaya sebagai daerah pusat pertumbuhan dan Kabupaten/Kota Gresik, Bangkalan, Mojokerto, Sidoarjo dan Lamongan sebagai daerah pendukung pusat pertumbuhan.

Keadaan tersebut memiliki dampat negatif yakni terserapnya modal dan tenaga kerja ahli sebagai sumberdaya pembangunan ke daerah pusat pertumbuhan yakni Kota Surabaya. Akibatnya sumberdaya pembangunan (modal dan tenaga ahli) dari Kabupaten/Kota Gresik, Bangkalan, Mojokerto, 
Sidoarjo dan Lamongan terserap ke Kota Surabaya. Sehingga kegiatan ekonomi tekonsentrasi di Kota Surabaya dan tidak ada pergerakan pertumbuhan ekonomi dari pusat pertumbuhan (Kota Surabaya) ke daerah pendukung yang menyebabkan trickle down effect (dampak penyebaran) yang diharapkan tidak terjadi.

Kota Surabaya memiliki karakteristik yang sedikit berbeda dibandingkan keenam Kabupaten/Kota lainnya karena Surabaya merupakan pusat dari kegiatan perekonomian, sedangkan Kabupaten/Kota lainnya merupakan penyokong dari kegiatan ekonomi Surabaya. Surabaya merupakan Kota Metropolitan terbesar kedua setelah Jakarta. Hal ini menggambarkan bahwa Kota Surabaya merupakan pusat perdagangan bagi Kabupaten/Kota disekitarnya namun suplay komoditi perdagangan dan tenaga kerja kebanyakan berasal dari daerah penyokong yakni Gresik, Bangkalan, Mojokerto, Sidoarjo dan lamongan. Fenomena tersebut akan semakin memperlebar kesenjangan atau disparitas ekonomi antar daerah. Hal inilah yang menjadikan Kota Surabaya memiliki Disparitas pendapatan yang tinggi dibandingkan keenam Kabupaten/Kota lainnya. Jadi dapat disimpulkan bahwa wajar jika terjadi perbedaan tingkat disparitas antara Kota Surabaya dan Kabupaten/Kota lainnya karena karakteristiknya juga berbeda.

Disamping itu yang menyebabkan adanya perbedaan disparitas pendapatan adalah tingkat pendidikan penduduk minimal SMA yang diasumsikan mempunyai keterampilan dan pengetahuan tinggi, sehingga dapat menyerap teknologi modern dan meningkatkan kapasitas produksi yang pada akhirnya akan meningkatkan pendapatannya sesuai dengan tingkat pendidikannya. Jika tingkat pendidikan berkorelasi dengan pertumbuhan ekonomi tentunya akan berdampak pada disparitas pendapatan. Hal ini terjadi karena peningkatan pendidikan berdampak pada percepatan pertumbuhan ekonomi dimana penduduk yang berpendidikan tinggi dapat memanajemen perusahaan-perusahaan yang berkembang dengan efisien, mempercepat perkembangan penggunaan teknologi modern dalam kegiatan ekonomi dan pendidikan yang lebih tinggi dapat meningkatkan daya pemikiran masyarakat. Sehingga gabungan pengaruh yang ditumbulkan dari tingkat pendidikan dan pertumbuhan ekonomi akan sangat berdampak pada tingginya disparitas pendapatan.

Dengan demikian, hipotesis yang menyatakan bahwa ada pengaruh antara pertunbuhan ekonomi dan tingkat pendidikan terhadap disparitas pendapatan diterima atau terbukti kebenarannya.

\section{SIMPULAN}

Dari pemaparan di atas maka dapat disimpulkan: pertama, tidak ada pengaruh signifikan pertumbuhan ekonomi terhadap disparitas pendapatan Gerbangkertosusila dan kedua variabel tersebut memiliki hubungan positif. Hasil temuan menunjukkan bahwa beberapa indikator pertumbuhan ekonomi yakni output produksi barang industri, barang modal dan sektor jasa tidak dapat terdistribusi secara merata dan hanya terkonsentrasi pada masyarakat kelas atas. Kedua, pengaruh tingkat pendidikan terhadap disparitas pendapatan Gerbangkertosusila adalah signifikan dan negatif. Hal ini menunjukkan bahwa 
tingkat pendidikan yang tinggi menjamin adanya pemerataan distribusi pendapatan. hasil temuan menunjukkan bahwa jumlah penduduk Kota Surabaya yang berpendidikan tinggi lebih banyak dibandingkan Keenam Kabupaten/Kota lainnya namun memiliki disparitas pendapatan yang tinggi pula. Ketiga, pengaruh pertumbuhan ekonomi dan tingkat pendidikan terhadap disparitas pendapatan Gerbangkertosusila adalah signifikan. Hal ini menggambarkan bahwa kedua variabel independen tersebut memiliki dampak dalam pembentukan disparitas pendapatan Gerbangkertosusila. Hasil temuan menunjukkan bahwa adanya perbedaan disparitas pendapatan yang lebih tinggi pada Kota Surabaya karena Kota Surabaya merupakan daerah nodal dan keenam daerah lainnya merupakan daerah pendukung sehingga kesenjangan semakin tinggi antara daerah nodal dan daerah pendukung.

\section{DAFTAR RUJUKAN}

Abdullah, Abdul Jabbar, 2011. Education and Income Inequality: A MetaRegression Analysis. JEL Codes: I24, C01

Ali, Sharafat, 2014. Inflation, Income Inequality and Economic Growth in Pakistan: A Cointegration Analysis. International Journal of Economic Practices and Theories. Vol. 4, No. 1, Summer 2014. pp. 33-42.

Arikunto, Suharsimi, 2010. Prosedur Penelitian Suatu Pendekatan Praktik. Jakarta: Rineka Cipta.

Arsyad, Lincolin, 2010. Ekonomi Pembangunan (Edisi Revisi 5). Yogyakarta: UPP STIM YKPN.

Carnoy, M., Loyalka, P., Androuschak, G., 2012. Does Expanding Higher Education Equalize Income Distribution? The Case of the BRIC Countries. Working Papers. Center for Education Policy Analysis: Stanford University.

Das, Samarjit dkk., 2014. Economic growth and income inequality: examining. Journal of Quantitative Economics, Vol. 12, No.1. Summer 2014. pp. 8695.

Deliarnov. (2009). Perkembangan Pemikiran Ekonomi. Jakarta: PT Grafindo Persada

Gama, Ayu Savitri, 2007. Disparitas dan Konvergensi Produk Domestik Regional Bruto (PDRB) Per Kapita Antar Kabupaten/Kota di Provinsi Bali. Jurnal Ekonomi dan Sosial Vol. 2 No. 1

Gujarati, Damodar N., 2006. Ekonometrika Dasar. Jakarta : Penerbit Erlangga.

Hoi, Chu Minh \& Le Quoc Hoi, 2012. Financial Development and Income Inequality in Vietnam: An Empirical Analysis. Journal of Economics and Development Vol. 14, No.2. Summer 2012. pp. 5-25

Ibourk, Aomar \& Jabrane Amaghouss, 2013. Inequality in Education and Economic Growth: Empirical Investigation and Foundations - Evidence 
from MENA Region. International Journal of Economics and Finance Vol. 5, No. 2. Summer 2013. pp. 111-124.

Juwita, Ratna \& Retno Budi Lestari, 2013. Kontribusi Tingkat Pendidikan Terhadap Pendapatan Sektoral Di Kota Palembang. Jurnal Ilmiah STIE MDP Vol. 2 No. 2

Kuncoro, Mudrajad, 2006. Ekonomi Pembangunan: Teori, Masalah dan Kebijakan. Yogyakarta: UPP AMP YKPN.

Lee, Hae Young dkk., 2013. Empirical Analysis on the Determinants of Income Inequality in Korea. International Journal of Advanced Science and Technology Vol. 53. Summer 2013. pp. 95-110.

Lin, Chun-hung A., 2007. Education expansion, educational inequality,And income inequality: evidence from taiwan,1976-2003. Social Indicators Research 80. Summer 2007. pp. 601-615.

Prapti, Lulus, 2006. Keterkaitan antara pertumbuhan Ekonomi dan distribusi pendapatan (Studi Kasus 35 Kabupaten/Kota Jawa Tengah 2000-2004). Tesis Diterbitkan.

Raswita, Ngaka Putu Mahesa \& Made Suryana Utama, 2013. Analisis Pertumbuhan Ekonomi dan Ketimpangan Pendapatan Antar Kecamatan di Kabupaten Gianyar. E-Jurnal EP Unud Vol. 2 No. 3. Summer 2013. pp. $119-128$

Riandoko, Benedictus dkk., 2013. Pengaruh Pertumbuhan Ekonomi, Share Sektor Industri Dan Pertanian Serta Tingkat Jumlah Orang Yang Bekerja Terhadap Ketimpangan Wilayah Antar Kabupaten/Kota Di Jawa Tengah Tahun 2002-2010. Jurnal Ekonomi Vol. 2 No. 1. Summer 2013. pp. 1-14

Shochrul R, Ajija, dkk. 2011. Cara cerdas menguasai EVIEWS. Jakarta : Salemba Empat

Sugiyono, 2011. Statistik untuk Penelitian. Bandung: Alfabeta.

Sukirno, Sadono, 2010. Ekonomi Pembangunan: Proses, Masalah, dan Dasar Kebijakan (edisi ke-2). Jakarta: Kencana Prenada Media Group.

Sultan \& Jazani Sodik, 2010. Analisis Ketimpangan Pendapatan Regional di DIY-Jawa Tengah serta faktor-fakto yang Mempengaruhi Periode 20002004. Buletin Ekonomi Vol. 8 No. 1. Summer 2010. pp. 33-44.

Szeles, Monica Raileanu, 2013. Re-examining the relationship between economic growth and inequality in the New Member States. Qual Quant. Summer 2013. Pp. 2799-2813

Teulings, Coen \& Thijs van Rens, 2008. Education, Growth and Income Inequality. Review of Economics and Statistics, 90 (1). Summer 2008. pp. 89-104.

Todaro, Michael P., 2006. Pembangunan Ekonomi di Dunia ketiga. Jakarta: Erlangga. 
Todaro, Michael P. \& Stephen C. Smith, 2006. Pembangunan Ekonomi Edisi Kesembilan. Jakarta: Erlangga. 